 \\ Journal of \\ Human, Earth, and Future
}

ISSN: 2785-2997

Vol. 2, No. 3, September, 2021

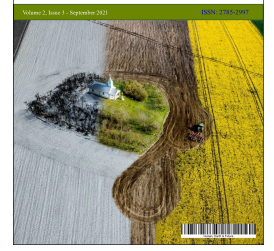

\section{Introducing a Model for Infrastructure Improvement to Develop Intelligent Schools}

\author{
Somaieh Alavi ${ }^{1 *} \odot$ \\ ${ }^{1}$ Department of Industrial Engineering, Faculty of Engineering, Shahid Ashrafi Esfahani University, Isfahan, Iran
}

Received 18 June 2021; Revised 19 August 2021; Accepted 23 August 2021; Published 01 September 2021

\begin{abstract}
Intelligent schools have faced many challenges, and little research has been conducted to review the challenges of developing these schools. There are models for solving the challenges and barriers to the implementation and development of such schools, but still, the challenge of infrastructure is considered the most fundamental challenge in the development of intelligent schools. In this paper, a model is proposed to solve the problem of infrastructure in the development of intelligent schools by identifying important features based on the existing features regarding the creation of intelligent schools. This model was evaluated by ten experts in the implementation of intelligent schools. The proposed model can be used to improve the problems of infrastructure in the process of creation and implementation of intelligent schools.
\end{abstract}

Keywords: Information and Communication Technology; Infrastructure; Intelligent Schools.

\section{Introduction}

Information and Communication Technology (ICT) provides many opportunities and platforms for education and is used as a tool for facilitating and sometimes precipitating the educational process [1]. Rapid development in ICT and evolving learner behaviors require learning institutions to continuously reevaluate their approaches [2]. An intelligent school is an institution based on the Teaching-Learning process and its control and management are based on ICT, which is also responsible for preparing students with effective capabilities concerning intelligent schools. Intelligent schools not only stimulate thinking and creativity but also consider individual differences [3].

Intelligent education emphasizes the role of IT because the purpose of intelligent education is to improve the learning experience in solving learners' various requirements through the innovative use of ICT [4]. The integration of ICT into education affects educational systems in many ways, and learners' and teachers' lives are affected by the extent of their involvement with this technology [5]. The integration of ICT into education has focused on student-centered education and self-directed learning [6]. Moreover, students become more capable of using information and data from a variety of sources [7, 8]. The use of ICT in education in intelligent schools increases students' motivation and educational achievement. In addition, it reduces student interactions and students' dependency on school [9, 10]. The results of the study concerning the differences and effects of education in intelligent schools compared to traditional schools revealed that in intelligent school students' motivation, learning skills, and educational accomplishment is higher than students in traditional school [11].

\footnotetext{
* Corresponding author: somayeh_alavi61@yahoo.com

$>$ This is an open access article under the CC-BY license (https://creativecommons.org/licenses/by/4.0/).

(C) Authors retain all copyrights. 
For effective participation of all social groups in such a society, participants need to possess creativity, continuous learning, innovation, and active and social participation, and this requires a new redefinition of the role and function of schools as the main educational institution in society. Intelligent schools are one of the key requirements of a knowledgebased society, as well as a method for developing knowledge and entrepreneurship skills [12]. Furthermore, the importance of intelligent schools as a competitive factor among countries is another reason for addressing this issue. In this regard, in order to achieve a desired level of ICT-based programs, the existence of an appropriate educational technology infrastructure is necessary. Hence, in order to develop an intelligent school, a model should be proposed that could determine the process of creating such schools, which can be used as a reference for the development of intelligent schools that differentiate intelligent schools from traditional schools.

The models introduced in recent years have considered only some of the important features of infrastructure and have not identified the exact road map for the development of intelligent schools. The purpose of this paper is to propose a model for solving the problem of infrastructure for developing intelligent schools by identifying important and essential features based on the existing specifications for the creation of intelligent schools. These specifications and features follow the features of high-quality intelligent schools in advanced countries. The purpose of this model is to eliminate the problems and defects of previous models and to improve the process of creating and implementing intelligent schools in terms of infrastructure.

\section{Research Background}

Concerning research conducted in the context of intelligent schools, dimensions have been identified for creating and developing intelligent schools as well as the dimensions that have the greatest impact on the success of such schools. This paper will focus on dimensions such as the Teaching-Learning environment, training and evaluation, technology and processes, infrastructure, culture, rules and regulations, space, management and support. These dimensions are achieved based on a comparison made between models proposed in countries such as Finland, Malaysia, New Zealand, Australia and the United States, which are the main countries in developing intelligent schools, as well as the models proposed in Indonesia to develop and implement these schools. Table 1 illustrates the importance of each of these dimensions from the perspective of experts in this field. In the following, each of these dimensions will be introduced in order to reach the administrative domain. These dimensions are incorporated in the model to improve intelligent school conditions in Indonesia.

Table 1. Comparison of models and researches presented in the field of intelligent development

\begin{tabular}{|c|c|c|c|c|c|c|c|}
\hline Row & Researchers Dimensions & $\begin{array}{c}\text { Teaching- } \\
\text { Learning } \\
\text { environment }\end{array}$ & $\begin{array}{c}\text { Training and } \\
\text { Evaluation }\end{array}$ & Infrastructure & Culture & $\begin{array}{l}\text { Rules and } \\
\text { Regulation }\end{array}$ & $\begin{array}{l}\text { Management } \\
\text { and Support }\end{array}$ \\
\hline 1 & Mbuk [13] & & & $\otimes$ & & & \\
\hline 2 & Fernandes et al. [14] & $\otimes$ & $\otimes$ & $\otimes$ & & & \\
\hline 3 & Hubalovsky et al. [15] & & $\otimes$ & $\otimes$ & & $\otimes$ & \\
\hline 4 & Shanmugam and Balakrishnan, [16] & $\otimes$ & $\otimes$ & $\otimes$ & & & $\otimes$ \\
\hline 5 & Soegoto et al. [17] & & & $\otimes$ & & & $\otimes$ \\
\hline 6 & Shoikova\&etal [18] & $\otimes$ & & $\otimes$ & & & \\
\hline 7 & Jalali et al. [19] & $\otimes$ & & $\otimes$ & & & $\otimes$ \\
\hline 8 & Taleb and Hassanzadeh [20] & & $\otimes$ & $\otimes$ & & & \\
\hline 9 & Niemi [21] & & $\otimes$ & & & & $\otimes$ \\
\hline 10 & Omidinia et al. [22] & $\otimes$ & & & & & \\
\hline 11 & Soltani [23] & $\otimes$ & $\otimes$ & $\otimes$ & & $\otimes$ & \\
\hline 12 & Kikis et al. [5] & $\otimes$ & & & & & \\
\hline 13 & Ilomaki [24] & $\otimes$ & $\otimes$ & & $\otimes$ & & \\
\hline
\end{tabular}

\subsection{The Importance of Teaching-learning Dimension}

The use of multimedia and electronic content in the teaching-learning process is the main element of an intelligent school. One of the most important features of intelligent schools is that students use independent thinking and creativity, and the created environment makes the capabilities of teachers and parents to strengthen education. Intelligent school environments provide a platform for increasing student's motivation, and enable students to learn efficiently. Moreover, in intelligent schools, the teaching-learning process is not limited to the hours of students attending school and students can learn and practice curriculum concepts outside school through the use of content management systems [11]. Using application teacher, students and parents can collaborate on a single podium, while teachers can counsel students in a real-time and share interact with parents as well as administrators [25]. 


\subsection{The Importance of Training and Evaluation Dimension}

Another challenge that faces intelligent schools is the lack of qualified teachers. For intelligent schools to be effective, teachers should possess IT skills and have ICDL (International Computer Driving License) or other relevant certificates. Ong et al. conducted a study to evaluate student achievement in teaching science in an intelligent school by comparing two schools, an intelligent school with a traditional one. Even though the Malaysian intelligent school initiative is intended to prepare students in the developing economy and to enhance their scientific and technological knowledge, the study results showed that student achievement were not as expected [26, 27]. Ming et al. (2010) indicates this to be due to the lack of teacher training and professional development [28]. As a result, first, before employing teachers to teach in intelligent schools, there should be an initial training class regarding the mastery of the subject, managerial skills, and the use of various educational tools. According to the studies a suitable framework should be considered to employ qualified teachers in intelligent schools.

As information technology facilitates processes such as administrative, organizational and managerial processes, technology education at all levels is suggested specifically. In this regard, ICT education should be compulsory in the teacher training and pre-service curriculum field, rather than an optional part [29]. Another important issue in this dimension is the important role that monitoring and evaluation plays in the teaching and learning process. Evaluation should be conducted in all areas, such as curriculum, classroom interactions, teacher-student communication, and teacher performance, learning tools, and teaching methods. Evaluation is measured based on certain indicators to determine teacher effectiveness and the extent of their educational impact on students. In doing so, the direction of the current move can be identified and problems can be solved [30,31].

\subsection{The Importance of Infrastructure Dimension}

Unfortunately, the structure and organization of schools in developing countries, including Indonesia, which is the subject of this article, is quite traditional and IT has no place. Information technology plays a key role in intelligent schools; therefore, it is necessary to adapt the structure and organization of schools in Indonesia with information technology. The development of IT infrastructure is one of the requirements of an intelligent school. It should be noted that Infrastructure will be developed in such a way to cover the requirements to use electronic content in the teachinglearning process. Much attention regarding infrastructure focuses on hardware resources and the teaching-learning process is forgotten [32]. Previous studies have shown that there is a complete conflict between the levels of student satisfaction with high quality infrastructure compared to schools with weaker infrastructure [33, 34]. Hence, according to studies conducted by the University Antwerp Belgium on the infrastructure of intelligent schools, the results indicated that the infrastructure will contribute to $100 \%$ students' welfare and motivation to continue their education, and addressing infrastructure settings can enhance student motivation and bring good benefits. In this regard it can be concluded that having a suitable infrastructure will cause students use greater information with a greater capacity that helps them to succeed in future $[33,35]$. For example, the study of Ali et al. on intelligent schools showed that teachers faced problems during the process of integrating ICT at their school. Problems include time constraints, non-relevant course content, and technology issues such as server failure. Moreover, teachers claimed that they could not finish their lessons according to the time available because technical problems occurred during the teaching process and issues of access to ICT equipment have affected the integration of ICT into the curriculum [36]. As a result, unsuitable infrastructure reduces teachers' motivation and increases their resistance to change [37].

\subsection{The Importance of Culture Dimension}

Now days, one of the most controversial issues, especially in developing countries, is culture, because culture is considered to be the basis of intellectual and epistemic life of a society. Before using any instrument, the science of its use must be learned, the educational system must also strive to provide the ground for this technology to enter into the education system. According to the Indonesian Ministry of Education, One of the major problems in intelligent schools is the lack of culture in this regard, and the goal of an intelligent school, which is the use of IT to increase deep and comprehensive learning, should be described for families and teachers [16].

\subsection{The Importance of Management and Support Dimension}

One of the important factors in the success of the ICT development program in the ministry of education is knowledge ability, capability and quality of management and leadership. School principals are actually the leaders of ICT development programs, and for playing this great role, they should have the necessary abilities to use effective management methods to provide the necessary coordination among the school elements to support the goals. According to recent research regarding intelligent schools' management in Malaysia, the plan to develop intelligent schools is a national effort for innovative education. It also condemns school principals to use ICT at the administrative and classroom level to use systems and soft wares. According to the results of the study the use of these facilities by school principals has reduced costs, time and human resources, which shows the importance of using technology in classroom management [16]. According to the recent studies in Indonesia, it can be understood that not much attention has been paid to support issues, which is one of the key factors in management that has led to poor student performance in Indonesia. 


\subsection{The Importance of Rules and Regulation Dimension}

The lack of rules and regulations required in Indonesia's ministry of education is considered one of the most important challenges, so that the lack of such regulations has caused a big gap between Indonesian intelligent schools and international standards. Since in intelligent schools, monitoring and evaluation are based on computer technology and intelligence, the legal frameworks required are different with regards to traditional schools [38]. This requirement comes from the difference between intelligent and traditional schools. The lack of regulations in the field has caused many problems in schools. For example; teachers do not take responsibility to provide multimedia curriculum, and if a teacher prepares the content with personal interest, there is no law for financial compensation [39]. Today, intelligence schools are considered as a competitive factor among countries, so education department regulations plays a key role in this regard $[40]$.

\section{Research Methodology}

The proposed model has been constructed by identifying the important dimensions in developing intelligent schools based on the existing models in the literature. For this reason, each dimension was studied further so that correct comparisons could be made and the deficiencies and weaknesses in the field could be mentioned. Therefore, in order to address each dimension in a precise and detailed way, indicators along with their benefits are discussed below which will help the executer to implement the plan for developing intelligent schools in such a way that these indicators express the importance of the dimension and the weaknesses of intelligent schools. A questionnaire was developed based on a five point Likert scale and was answered by ten experts in this field. Finally, the results were evaluated by the Delphi method in two steps.

In the Delphi method, after collecting information through literature review, the questionnaire was given to experts in order to evaluate the dimensions and the indicators identified. After receiving expert opinions and calculating the average of the responses, indexes below the average of 3 were eliminated. Then a questionnaire was presented to the experts by deleting questions with value less than 3. After receiving expert opinions at this stage, the results of both stages were reviewed and compared. Experts agreed on an index if the average difference of experts' views for an indicator in the two steps was less than 0.1 . The steps continue until experts agree on all the indicators. Furthermore, any indicator that gained at least an average of 3 based on experts' opinions remained as an important indicator in the process. Subsequently, based on the results of the Delphi questionnaire, a model for the implementation of intelligent schools was proposed.

\section{Data Analysis}

After receiving the questionnaires filled out by experts, the average of each question was calculated, and thus the value of each indicator was determined. Indexes with an average of less than 3 were excluded and were not included in the second phase. Afterwards, the mean for each question in the questionnaire in the second stage was determined and the difference between the mean of the first and second stages was calculated. All differences were less than 0.1, which means that the experts had agreed on the indicators considered for each dimension. In Table 2, the analysis of the findings and the values of the indicators for each of the six dimensions are presented.

Table 2. Mean of questions in the first and second round and their differences using the Delphi method

\begin{tabular}{|c|c|c|c|c|c|c|}
\hline Dimensions & Row & Indicators & Benefits & $\begin{array}{c}\text { Mean of } \\
\text { questions in } \\
\text { first round }\end{array}$ & $\begin{array}{c}\text { Mean of } \\
\text { questions in } \\
\text { second round }\end{array}$ & $\begin{array}{l}\text { Differenc } \\
\text { e means }\end{array}$ \\
\hline \multirow{6}{*}{ 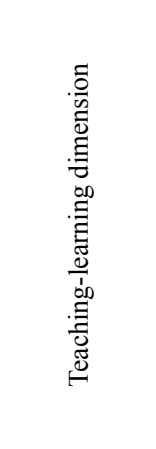 } & 1 & Teaching strategies [39] & $\begin{array}{l}\text { Ensure the development and promotion of } \\
\text { creativity. }\end{array}$ & 3.64 & 3.79 & -0.15 \\
\hline & 2 & The use of supplementary software & $\begin{array}{l}\text { Communication with students outside of } \\
\text { school. }\end{array}$ & 4.22 & 4.29 & -0.07 \\
\hline & 3 & $\begin{array}{l}\text { Communicate with other intelligent } \\
\text { schools [21] }\end{array}$ & Sharing resources and research. & 3.83 & 3.75 & 0.08 \\
\hline & 4 & Student-cantered [21] & $\begin{array}{l}\text { Better use of intelligence of students and } \\
\text { teachers. }\end{array}$ & 3.01 & 3.1 & -0.09 \\
\hline & 5 & $\begin{array}{l}\text { Appropriate assessment of students' } \\
\text { talent [41] }\end{array}$ & $\begin{array}{l}\text { Establishment of criteria and selection } \\
\text { based on students' creativity and } \\
\text { intelligence. }\end{array}$ & 2.01 & ---- & ---- \\
\hline & 6 & $\begin{array}{l}\text { Flexible teaching according to student } \\
\text { intelligence [39] }\end{array}$ & Creating motivation. & 3.1 & 3.15 & 0.05 \\
\hline \multirow{2}{*}{ 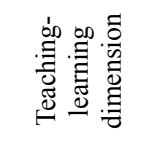 } & 7 & $\begin{array}{l}\text { Editing Challenges, Motivations and } \\
\text { types of teaching methods absorber [42] }\end{array}$ & $\begin{array}{l}\text { Continuous activity of the student in the } \\
\text { learning environment. }\end{array}$ & 3.93 & 4.19 & -0.026 \\
\hline & 8 & $\begin{array}{l}\text { Smart curriculum development and time } \\
\text { management [21] }\end{array}$ & Use more content and motivate the student. & 4.21 & 4.27 & -0.06 \\
\hline
\end{tabular}




\begin{tabular}{|c|c|c|c|c|c|c|}
\hline \multirow{8}{*}{ 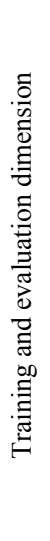 } & 9 & $\begin{array}{l}\text { Holding technology learning courses and } \\
\text { ICDL [42] }\end{array}$ & $\begin{array}{l}\text { Having skilful teachers and tailored to the } \\
\text { intelligent schools. }\end{array}$ & 4.11 & 4.1 & 0.01 \\
\hline & 10 & $\begin{array}{l}\text { Induction of technology in teaching } \\
\text { methods and courses [42] }\end{array}$ & Create interest and motivation in students. & 3.92 & 3.97 & -0.05 \\
\hline & 11 & $\begin{array}{l}\text { Editing the plan for monitoring and } \\
\text { evaluation }\end{array}$ & $\begin{array}{l}\text { Examining teacher skills and rating them } \\
\text { and getting feedback. }\end{array}$ & 3.95 & 3.89 & 0.06 \\
\hline & 12 & $\begin{array}{l}\text { Attention to education field and } \\
\text { documents obtained degree. }\end{array}$ & Having knowledge in the field of teaching. & 1.26 & ---- & ---- \\
\hline & 13 & Psychology courses & Teachers' resistance to change. & 3.81 & 3.84 & -0.03 \\
\hline & 14 & Teacher training time $[43]$ & $\begin{array}{l}\text { Keep teachers updated, tailored to the } \\
\text { technologies and information of the day. }\end{array}$ & 3.93 & 3.95 & -0.02 \\
\hline & 15 & $\begin{array}{l}\text { Special test to enter the intelligent } \\
\text { schools }\end{array}$ & $\begin{array}{l}\text { Existence Proper teachers to intelligent } \\
\text { schools. }\end{array}$ & 1.8 & ---- & ---- \\
\hline & 16 & Due to the age of teachers & $\begin{array}{l}\text { Having excitement and improve } \\
\text { communication with students }\end{array}$ & 2.3 & ---- & ---- \\
\hline \multirow{7}{*}{ 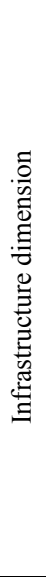 } & 17 & $\begin{array}{l}\text { Existence of sufficient numbers of } \\
\text { personal computers and tablets for } \\
\text { students }[21,44]\end{array}$ & $\begin{array}{l}\text { Access to electronic content and use of this } \\
\text { content }\end{array}$ & 3.92 & 4 & -0.08 \\
\hline & 18 & $\begin{array}{l}\text { There are a sufficient number of } \\
\text { peripherals (printers, scanners, etc.) and } \\
\text { smart systems at school [21] }\end{array}$ & $\begin{array}{l}\text { Utilization for use by teachers, students and } \\
\text { administrative officers. }\end{array}$ & 3.03 & 3.12 & -0.09 \\
\hline & 19 & $\begin{array}{l}\text { Existence of sufficient numbers of } \\
\text { projector for each class [21] }\end{array}$ & For traditional schools. & 4.06 & 4.08 & -0.02 \\
\hline & 20 & $\begin{array}{l}\text { Existence of appropriate computer sites } \\
\text { [39] }\end{array}$ & $\begin{array}{l}\text { In case of lack of personal computers and } \\
\text { tablets. }\end{array}$ & 3.54 & 3.56 & 0.02 \\
\hline & 21 & $\begin{array}{l}\text { Internet access with bandwidth suitable } \\
{[39,45]}\end{array}$ & $\begin{array}{l}\text { Search content related to courses and } \\
\text { deepens the learning process. }\end{array}$ & 3.80 & 3.93 & -0.13 \\
\hline & 22 & $\begin{array}{l}\text { Existence of suitable laptop numbers for } \\
\text { every teacher }[21,39]\end{array}$ & $\begin{array}{l}\text { Content production, presentation and better } \\
\text { use of information. } \\
\text { Content management and learning } \\
\text { management }\end{array}$ & 4.16 & 4.11 & 0.05 \\
\hline & 23 & The updated site for school [46] & $\begin{array}{l}\text { Content management and learning } \\
\text { management. }\end{array}$ & 3.04 & 3.05 & -0.01 \\
\hline \multirow{14}{*}{ 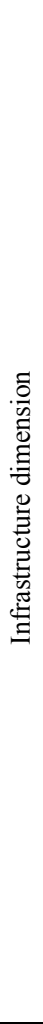 } & 24 & $\begin{array}{l}\text { Existence of e-mail for teachers and } \\
\text { students }\end{array}$ & $\begin{array}{l}\text { Continuous communication between } \\
\text { teachers, students and their parents. }\end{array}$ & 4.29 & 4.3 & 0.01 \\
\hline & 25 & $\begin{array}{l}\text { Existence of appropriate server at school } \\
\text { [39] }\end{array}$ & $\begin{array}{l}\text { Communication between PCs, user } \\
\text { management and permissions. }\end{array}$ & 3.07 & 3.1 & 0.03 \\
\hline & 26 & $\begin{array}{l}\text { Existence of emergency facilities in the } \\
\text { school [39] }\end{array}$ & $\begin{array}{l}\text { Continuation of the activities of computer } \\
\text { and servers. }\end{array}$ & 2.13 & ---- & ---- \\
\hline & 27 & $\begin{array}{l}\text { Suitable conditioning and cooling } \\
\text { equipment for the site [39] }\end{array}$ & $\begin{array}{l}\text { Better maintenance of the site and } \\
\text { electronic equipment. }\end{array}$ & 4.01 & 3.99 & 0.02 \\
\hline & 28 & $\begin{array}{l}\text { Existence of appropriate antivirus } \\
\text { software [39] }\end{array}$ & $\begin{array}{l}\text { Protect the school's intelligence resources } \\
\text { network against viruses. }\end{array}$ & 3.06 & 3.01 & 0.05 \\
\hline & 29 & $\begin{array}{l}\text { Deploying management system and } \\
\text { Users Support at school [39] }\end{array}$ & $\begin{array}{l}\text { Manage school computers and User access } \\
\text { control and set up resource usage policies. }\end{array}$ & 3.84 & 3.86 & -0.02 \\
\hline & 30 & Equip classes to smart boards [39] & $\begin{array}{l}\text { Creating attractiveness and accelerating the } \\
\text { teaching and learning process. }\end{array}$ & 4.11 & 4.06 & 0.05 \\
\hline & 31 & $\begin{array}{l}\text { Design and implementation of a } \\
\text { communication network, inside school }\end{array}$ & $\begin{array}{l}\text { Students' personal computer } \\
\text { communication with teacher and access } \\
\text { control }\end{array}$ & 3.01 & 3.16 & -0.15 \\
\hline & 32 & $\begin{array}{l}\text { Existence of a monitoring and evaluation } \\
\text { system. }\end{array}$ & $\begin{array}{l}\text { Determining the level of students and the } \\
\text { appropriate prospects for them. }\end{array}$ & 3.91 & 3.98 & -0.07 \\
\hline & 33 & Due to space & $\begin{array}{l}\text { Providing all the facilities for the } \\
\text { implementation of intelligent school. }\end{array}$ & 4.09 & 4.01 & 0.08 \\
\hline & 34 & $\begin{array}{l}\text { Integration management between } \\
\text { systems and other intelligent schools. }\end{array}$ & $\begin{array}{l}\text { Using of information and findings from } \\
\text { other intelligent schools. }\end{array}$ & 3.12 & 3.21 & -0.09 \\
\hline & 35 & Student card & $\begin{array}{l}\text { Attendance online and eliminating paper's } \\
\text { notebook. }\end{array}$ & 2.08 & ---- & ---- \\
\hline & 36 & Electronic Library & $\begin{array}{l}\text { Efficient use of Information and Search } \\
\text { online }\end{array}$ & 3.96 & 3.65 & 0.31 \\
\hline & 37 & Standard of Computer's desk and chair & $\begin{array}{l}\text { Resolving the Physical and psychological } \\
\text { Requirements of Students. }\end{array}$ & 3.94 & 4.2 & -0.026 \\
\hline \multirow{5}{*}{ 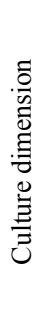 } & 38 & Planning for culture-making [45] & Organizing this subject & 4.14 & 4.2 & -0.06 \\
\hline & 39 & $\begin{array}{l}\text { Having the necessary advertising } \\
\text { (newspapers, billboards, etc.) }\end{array}$ & $\begin{array}{l}\text { Permanent engagement of people and } \\
\text { society with the issue of smart-making }\end{array}$ & 2.1 & ---- & --- \\
\hline & 40 & Holding meetings and conferences Free & $\begin{array}{l}\text { Expressing the benefits and impacts of } \\
\text { smart teaching content }\end{array}$ & 4.22 & 4.27 & -0.05 \\
\hline & 41 & Allocating funds for cultural activities & Having more effort to publicize this issue & 3.92 & 3.86 & 0.06 \\
\hline & 42 & $\begin{array}{l}\text { published books and articles related to } \\
\text { intelligent schools }\end{array}$ & Having more effort to publicize this issue & 3.99 & 3.91 & 0.08 \\
\hline
\end{tabular}




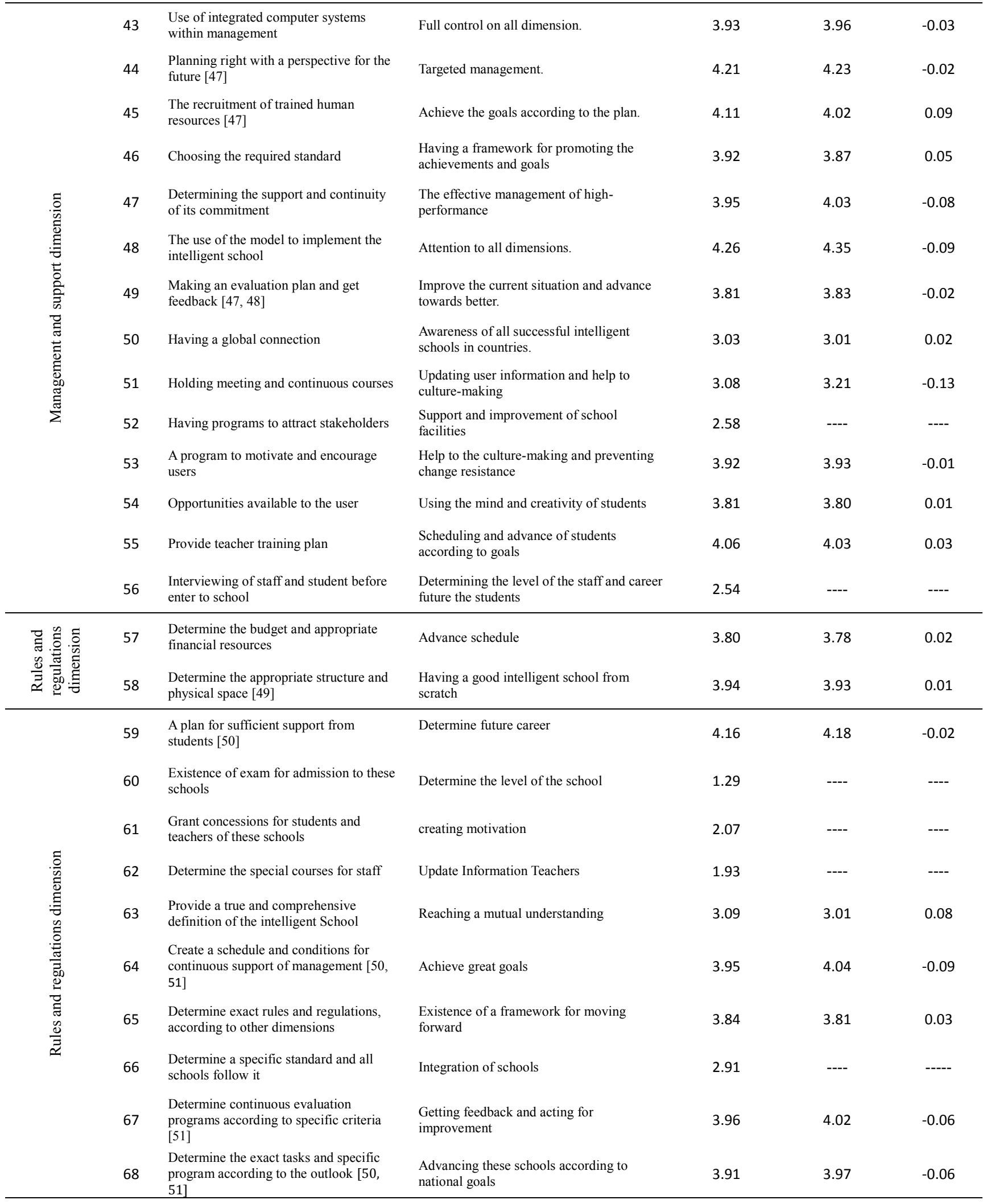

The rules and regulations dimension is a necessary component because intelligible schools need to make changes and add new regulations in this regard by the Ministry of Education, therefore; the managers and developers of such schools should act in accordance with these rules so that the schools would be in line with the projected outlook [52,53]. As seen in Figure 1, the rules and regulations dimension directly affects dimensions such as culture, management, and support, which means these dimensions should be in line with the rules and regulations imposed by the education organization.

The culture dimension has an important and constructive role in the creation and implementation of intelligent schools. One of the biggest problems of Indonesia in creating intelligible schools is the resistance of teachers and parents in using intelligent schools. Therefore, the dissemination of this culture can reduce resistance and can change the 
society's views of technology and its use in schools. So some specific solutions should be present in this regard. The culture dimension is regarded as the basic dimension of this model, and it is related to the management dimension. The Management and support dimension is very important in the establishment and implementation of intelligent schools. The manager should be a person who believes in this type of educational system and, by accepting the culture and rules governing intelligent schools, and should gather teachers and professionals in this field.

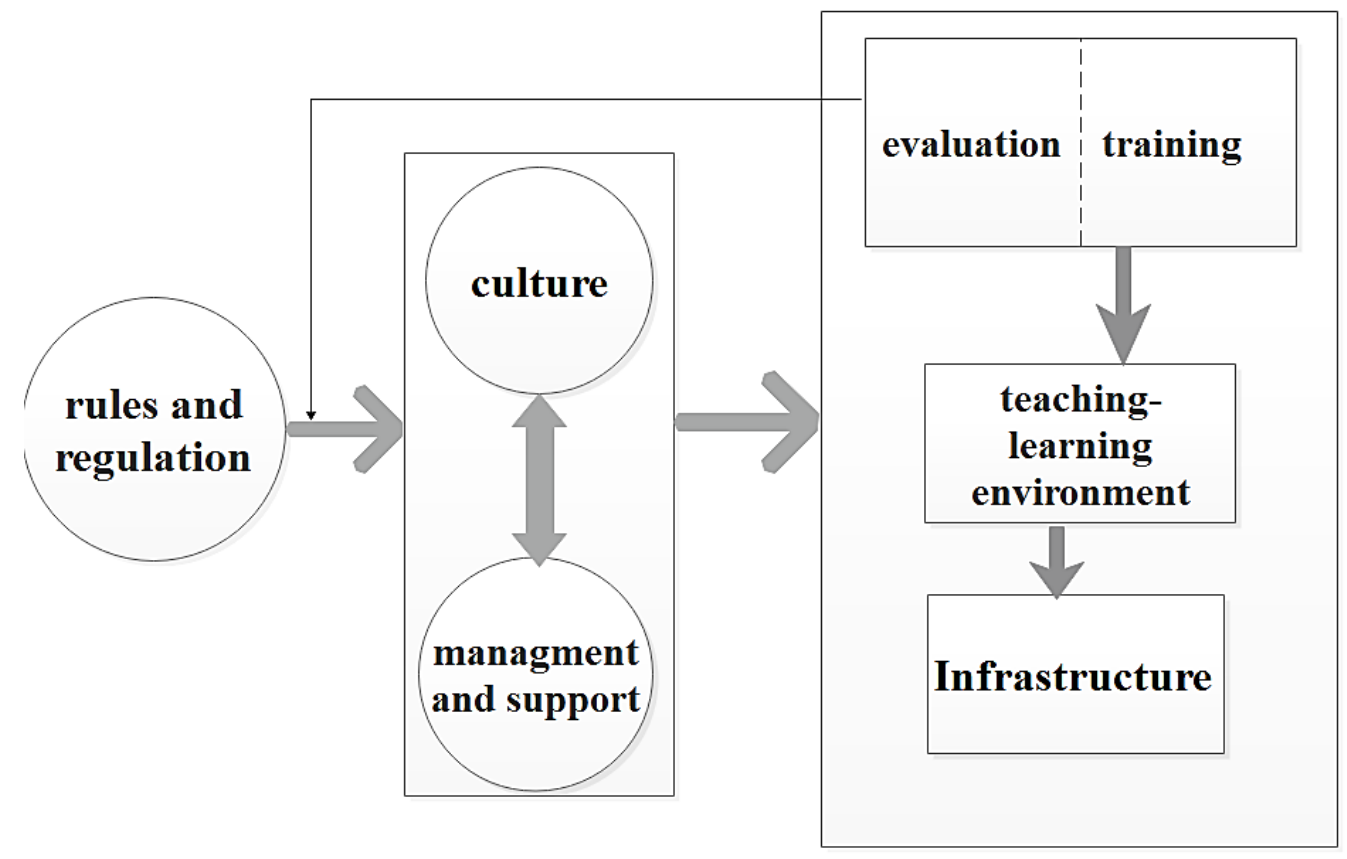

Figure 1. Intelligent school model

The manager must control infrastructure, training, evaluation and teaching-learning environment. According to recent studies, intelligent schools in Indonesia have a lot of weaknesses in the support dimension because of the lack of progress in such schools in the last few years. Another important dimension is training and evaluation which is based on the teaching-learning environment and infrastructure, and teachers and school staff should be trained to provide appropriate feedback. Evaluation is one of the factors that have been underestimated in Indonesia, and this is one of the reasons why Indonesia has not progressed in the field of intelligent schools. Therefore, continuous evaluation should be done according to the regulations. Evaluation includes teachers, school facilities and students. The results obtained from the evaluation and comparison between students of traditional and intelligent schools can be very useful in discussing the development of culture and attracting people to such schools.

The training and evaluation dimension, which is on the right side of the figure, is divided into two parts, and the training component directly relates to the dimensions of teaching-learning and infrastructure. The purpose is that training teachers is based on infrastructure and teaching-learning environment. In this model the evaluation section starts with the rules and regulations dimension, because all of the dimensions after school formation need to be evaluated to track the success in the school, and based on the results achieved special efforts have been made to improve intelligent school. The teaching-learning dimension should be defined properly for schools, and all facilities should be provided for the best possible feedback. Therefore, both teachers and managers in these schools should have special programs and strategies for this environment, as the conditions of this environment are completely different from traditional schools and require specific programs.

Infrastructure dimension is another important dimension. Most of the schools that consider themselves the intelligent school have been very weak in this dimension and even they have not basic facilities. Infrastructure for intelligent schools has significant features because intelligent schools work with technology and need to have the maximum facilities to present their science courses and content electronically.

\subsection{Method of Model Evaluation}

The proposed model was evaluated using a questionnaire. Questions for each dimension are proportional to their impact on other dimensions. According to the information obtained and the accuracy of each question, the validity of this model was obtained. The questionnaire consisted of 24 questions including a five point Likert scale for six dimensions. Five questions were dedicated to the culture dimension, four questions to the infrastructure dimension, five questions to the training and evaluation dimension, three questions to the management and support dimension, three questions to the teaching-learning dimension, and four questions to the rules and regulations dimension. 
Table 3. Mean, Cronbach's alpha and correlations of questionnaire

\begin{tabular}{|c|c|c|c|c|c|}
\hline Dimensions & Row & Questions & Mean & $\begin{array}{l}\text { Cronbach's } \\
\text { alpha }\end{array}$ & Correlations \\
\hline \multirow{4}{*}{ 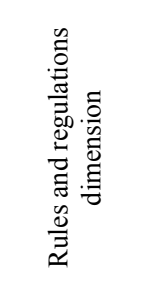 } & 1 & $\begin{array}{l}\text { The rigorous definition of rules by the education of ministry affects the use of } \\
\text { intelligent schools. }\end{array}$ & 4.21 & \multirow{4}{*}{0.770} & \multirow{4}{*}{0.389} \\
\hline & 2 & $\begin{array}{l}\text { The laws and regulations have a direct impact on the programs of the culture and the } \\
\text { management and support of these schools. }\end{array}$ & 4.02 & & \\
\hline & 3 & The rules and regulations are an essential part for the creation of intelligent schools. & 3.98 & & \\
\hline & 4 & Creating intelligent schools is very important in accordance with the raised rules. & 4.23 & & \\
\hline \multirow{5}{*}{ 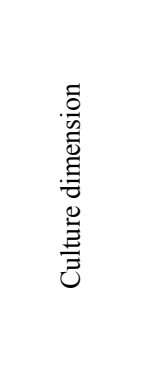 } & 5 & Culture-making influences the attraction of learners towards intelligent schools. & 4.11 & \multirow{5}{*}{0.764} & \multirow{5}{*}{0.365} \\
\hline & 6 & $\begin{array}{l}\text { Culture-making, based on a precise and continuous program, can directly affect the } \\
\text { community. }\end{array}$ & 3.92 & & \\
\hline & 7 & Culture-making about intelligent school minimizes society's resistance to this. & 3.95 & & \\
\hline & 8 & $\begin{array}{l}\text { Culture-making based on the educational environment and infrastructure will increase } \\
\text { the use of these schools. }\end{array}$ & 4.26 & & \\
\hline & 9 & $\begin{array}{l}\text { Culture is one of the main factors influencing the introduction and creation of } \\
\text { intelligent schools. }\end{array}$ & 4.2 & & \\
\hline \multirow{3}{*}{ 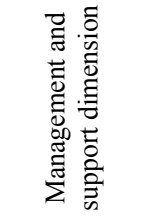 } & 10 & $\begin{array}{l}\text { Management along with planning affects the level of satisfaction of learners and } \\
\text { students in intelligent schools. }\end{array}$ & 3.92 & \multirow{3}{*}{0.734} & \multirow{3}{*}{0.378} \\
\hline & 11 & $\begin{array}{l}\text { Continuous support by ministry of education or education-dependent institutions of } \\
\text { intelligent schools will improve the performance of these schools. }\end{array}$ & 4.03 & & \\
\hline & 12 & Basic management and continuous support is essential in creating intelligent schools. & 3.99 & & \\
\hline \multirow{5}{*}{ 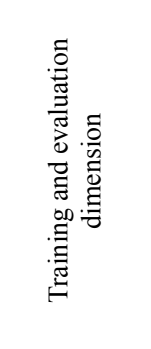 } & 13 & Teachers' training affects the quality of intelligent schools. & 3.93 & \multirow{5}{*}{0.721} & \multirow{5}{*}{0.394} \\
\hline & 14 & $\begin{array}{l}\text { Conducting periodic and continuous training in the field of intelligent schools is } \\
\text { essential. }\end{array}$ & 3.21 & & \\
\hline & 15 & $\begin{array}{l}\text { Continuous and planned evaluation influences the quality of the infrastructure and the } \\
\text { learning environment. }\end{array}$ & 4.11 & & \\
\hline & 16 & The high quality of training will be effective in attracting students to these schools. & 3.92 & & \\
\hline & 17 & Training and evaluation is essential for the growth of intelligent schools. & 3.54 & & \\
\hline \multirow{3}{*}{ 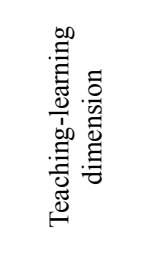 } & 18 & $\begin{array}{l}\text { The high quality of teaching-learning environment has a direct impact on the use and } \\
\text { output of these schools. }\end{array}$ & 3.80 & \multirow{3}{*}{0.713} & \multirow{3}{*}{0.341} \\
\hline & 19 & $\begin{array}{l}\text { Developing special programs and appropriate strategies based on the teaching- } \\
\text { learning environment is effective on the quality of intelligent schools. }\end{array}$ & 3.14 & & \\
\hline & 20 & $\begin{array}{l}\text { Teaching-Learning If it is programmed according to the facilities available at the } \\
\text { school, it will have a higher quality. }\end{array}$ & 3.91 & & \\
\hline \multirow{4}{*}{ 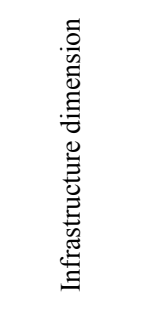 } & 21 & $\begin{array}{l}\text { The quality of infrastructure designed in intelligent schools affects the degree of } \\
\text { attraction and satisfaction of learners. }\end{array}$ & 3.91 & \multirow{4}{*}{0.712} & \multirow{4}{*}{0.397} \\
\hline & 22 & $\begin{array}{l}\text { The creation of infrastructure (space, smart systems, Internet, etc.) is required } \\
\text { according to the standards defined for intelligent schools. }\end{array}$ & 3.69 & & \\
\hline & 23 & Infrastructure will affect all aspects (training, teaching, learning, etc.). & 3.38 & & \\
\hline & 24 & $\begin{array}{l}\text { Lack of proper infrastructure causes the students to be dissatisfaction and do not use } \\
\text { intelligent schools. }\end{array}$ & 3.45 & & \\
\hline
\end{tabular}

The questionnaires were delivered manually for response. During the delivery of the questionnaires, explanations were provided to the experts about the goals of this research, so that they could easily answer the questions. The questionnaires were distributed to 32 experts in this field, in order to determine the importance of each dimension along with their indicators by the questions raised in the questionnaire.

\subsection{Results of Evaluation of Proposed Model}

Table 3 shows each item separately as well as the Cronbach's alpha and the correlation for the set of items for each model dimension. It should be noted that the Cronbach's alpha was calculated to measure the reliability of questions in each dimension and a score of above 0.7 means that it had acceptable reliability. One sample t-test was used for testing 
the hypothesis. The first hypothesis holds that the mean of scores given in the questionnaire on Likert scale stands between 1 and 5, less or equal to 3 (score 3 is taken for no idea), and the second hypothesis holds that the mean of scores given in the questionnaire is greater than 3 . But before running the test, the normality of the data should be examined. To do so, in order to determine the normality of scores given in the questions, Shapiro-Wilk \& Kolmogorov-Smirnov test was used. As seen in Table 4, the significance level of Shapiro-Wilk test was 0.069 and that of Kolmogorov- Smirnov was 0.127 , which is greater than 0.05 and means that data can be assumed to be normal with high a confidence level.

Table 4. Tests of Normality

\begin{tabular}{ccccccc} 
& \multicolumn{3}{c}{ Kolmogorov-Smirnov } & \multicolumn{3}{c}{ Shapiro-Wilk } \\
\cline { 2 - 7 } & Statistic & DF & Sig & Statistic & DF & Sig \\
\hline$Q_{\text {Mean }}$ & 0.131 & 32 & 0.127 & 0.931 & 32 & 0.069 \\
\hline
\end{tabular}

The overall mean of all items calculated in one sample t-test was 4.066, which is significantly different from the value of the hypothesis considered 3 . Table 5 shows statistics relating to the overall mean of all items such as mean $\&$ standard deviation. Table 6 which constitutes the results of one sample t-test, the significance level is not more than 0.05 ( $\operatorname{sig}=0.000$ ), so the first hypothesis is rejected and the second hypothesis is accepted.

Table 5. One-Sample Statistics

\begin{tabular}{ccccc} 
& $\boldsymbol{N}$ & Mean & Std. Deviation & Std. Error Mean \\
\hline$Q_{\text {Mean }}$ & 32 & 3.867 & 0.11766 & 0.03028 \\
\hline
\end{tabular}

Table 6. One-Sample Test

\begin{tabular}{ccccccc} 
& \multicolumn{6}{c}{ Test Value $=\mathbf{3}$} \\
\cline { 2 - 6 } & \multirow{2}{*}{ Test T } & DF & Sig & Mean Difference & 95\% Confidence Interval of the Difference \\
\cline { 3 - 6 } & & & & Lower & Upper \\
\hline$Q_{\text {Mean }}$ & 42.050 & 31 & 0.000 & 1.05406 & 1.0173 & 1.1061 \\
\hline
\end{tabular}

At the end, the Analytic Hierarchy Process (AHP) method also evaluated for the approved dimensions of the research. This method is one of the most widely used methods for ranking and determining the importance of factors, which uses a paired comparison of options to prioritize each dimension. Dimension ranking is shown in Table 7.

Table 7. Dimension ranking using AHP method

\begin{tabular}{clc}
\hline No. & \multicolumn{1}{c}{ Dimension } & Ranking \\
\hline 1 & Rules and Regulations & 1 \\
2 & Culture & 2 \\
3 & Management and Support & 3 \\
4 & Training and Evaluation & 4 \\
5 & Teaching-learning & 5 \\
6 & Infrastructure & 5 \\
\hline
\end{tabular}

According to the results obtained in Table 7 for the implementation of intelligent schools, it is first necessary to discuss the rules and regulations as a basic principle. The ministry of Education as a major source and general administration must re-evaluate the rules and regulations in accordance with intelligent schools and add new laws, as these schools are weak in the discussion of laws. According to the laws and regulations provided by the ministry of education, there is no rule not to employ people and teachers who do not possess ICT knowledge, and there is no law not to allow experienced teachers without ICT knowledge for working in these schools [14].

In the following, the culture dimension is discussed. According to the experts and studies conducted in this field, after rectifying the laws to attract teachers to continue their education and teaching in intelligent schools, in order to eliminate 
the community's resistance toward the use of technology in schools, disseminating appropriate culture is the initial step to achieve this objective. Therefore, it can be concluded that the Ministry of education, after reforming the rules, should continuously disseminate appropriate culture in this regard in order to see its impact in the coming years. After community acceptance in using intelligent schools and according to the framework developed by the Ministry of education, management should be addressed. The use of efficient and trained administrators will be invaluable in this field as the results indicate that proper management will affect the quality of factors such as infrastructure, training and teaching-learning.

Another important factor in this dimension is support. Due to lack of funding, many intelligent schools have not been able to operate or have very low quality. According to the proposed model, culture and management influence on the dimensions such as training and evaluation that are in fourth place in the ranking table. Training and evaluation are other important dimensions in the discussion of the implementation of intelligent schools, which is divided into two sections, first it is necessary to discuss the training that is carried out according to the teaching-learning environment. Teacher training for intelligent schools is important in accordance with the teaching-learning environment and the infrastructure available in schools, and special plans must be made in this field so that the school can observe the appropriate output. In this regard, according to the results of Table 7, the teaching-learning environment with infrastructure are in the same direction and rank, because first, intelligent schools must provide the appropriate infrastructure in accordance with the teaching-learning plan, in order to improve the quality of teaching-learning, satisfaction and motivation of the students.

Finally, the evaluation dimension should be carried out in all the dimensions and in accordance with the appropriate procedures. The results of this evaluation will improve the weaknesses in the different dimensions such as infrastructure, management, training, etc. Furthermore, since this evaluation can be done at all levels, the difference between the students in intelligent schools and traditional schools in terms of interest in continuing education, motivation, level of knowledge, etc. can be observed, which is affected by the culture that attracts learners to these schools. Therefore, Table 8 presents the proposed model theory map with respect to the arrangement of the dimensions in the presented model.

\subsection{Implementation of the Proposed Model}

To implement the model, a school that was not satisfied with the intelligence-related efforts was selected. Initially, the school conditions, all equipment, and facilities were identified. For example, the school was equipped with intelligent boards, data centers, computers, the Internet, websites, and applications. Then the school regulations regarding the use of electronic equipment were reviewed and some were modified. Meetings and conferences were then organized for teachers, pupils, and families to elucidate the benefits of intelligent schools. They were also informed about the shortages, difficulties, and disadvantages, and were asked to cooperate to get the best results. The school staff were relatively well prepared, but training classes were also arranged to give them the training needed to use electronic equipment. The teaching strategies determined were tailored to the teachers' teaching methods to their satisfaction. During one year of study, there was continuous monitoring of the classrooms. Finally, a general assessment was carried out with the school staff and the families, to determine how intelligent schools influence students' motivation and satisfaction. In general, the results obtained based on the model were acceptable, but the model faced several obstacles and problems described below, and if these problems are eliminated, the model could be more efficient. Such problems include:

- Lack of communication with other intelligent schools;

- Limited electronic content;

- The teachers' reluctance to take the time to attend training classes;

- Inappropriate Internet environment;

- Inappropriate training environment;

- Inappropriate seats;

- Resistance on the part of teachers and parents regarding the use of electronic equipment, websites and applications;

- Families not participating in free conferences;

- No fund allocated to cultural activities;

- Not having exciting programs to encourage teachers and parents;

- Lack of regulations for teachers' salary increase who are likely to work extra time. 
Table 8. The map of proposed model's theory

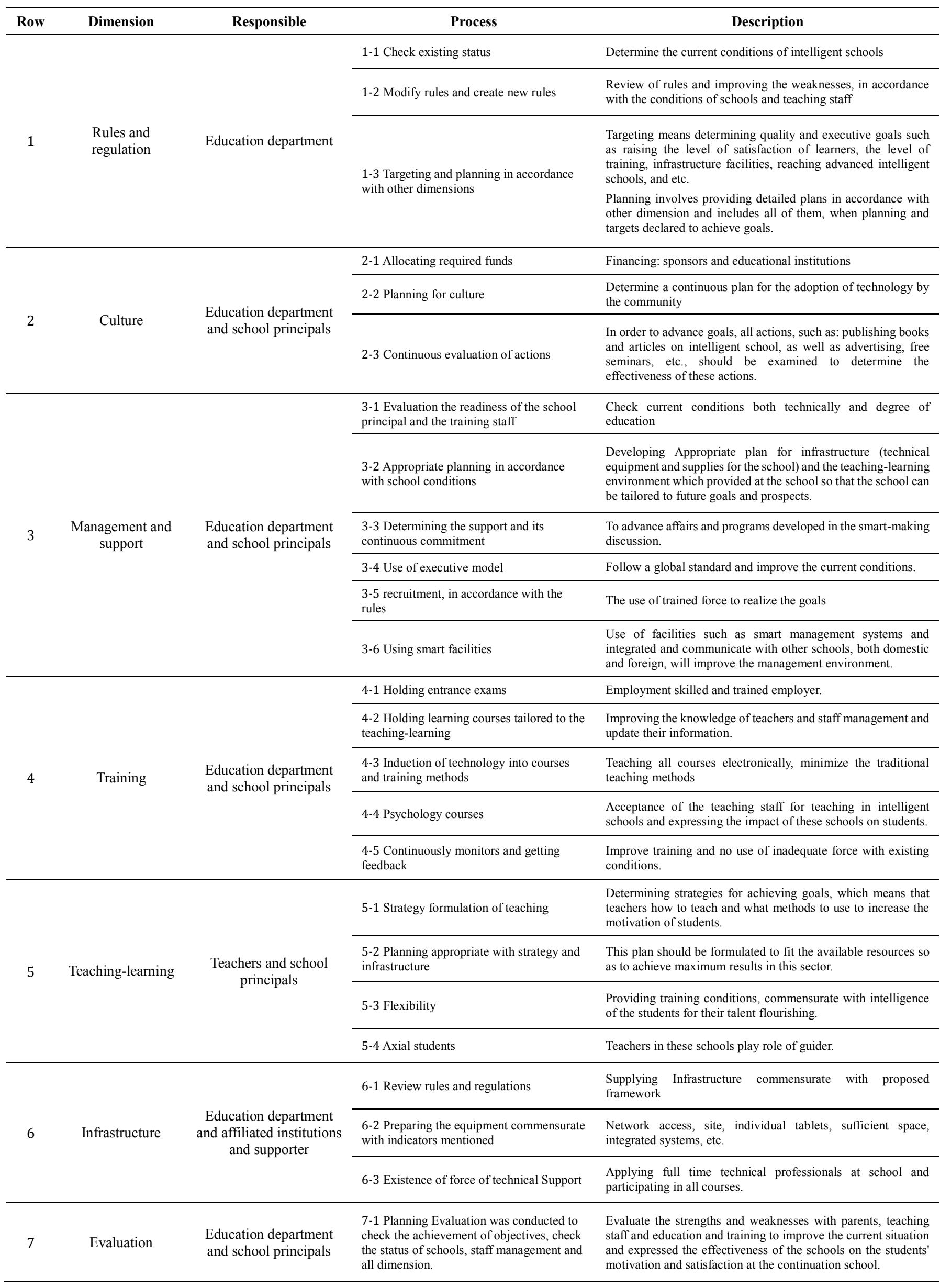




\section{Conclusion}

The use of modern educational technologies, like any other change, needs to change the structures, existing and traditional perspectives. The difficulties of using modern educational technology can be solved by developing the skills required in the field of education. The best strategy to change traditional teacher-centered to student-centered education and provide the appropriate conditions is to provide infrastructural conditions including dissimilating culture in the community, the acceptance of these changes by the educational community, and creating capacities in accordance with the needs and objectives of the educational system. The use of other countries' experiences in this field can accelerate this process.

It should be noted that teaching and learning using ICT and their interaction with traditional education is an important issue that must be considered by the community. Hence, the government should provide a suitable platform for the growth and improvement of the scientific level of the country by providing appropriate infrastructure. Infrastructures include high-speed Internet connections; providing affordable hardware and software; governmental support in scientific projects; and promoting electronic learning and intelligent schools among people. Therefore, the need for a model that includes the specified dimensions is vital since, according to the results obtained from the evaluation of the proposed model to improve the conditions for the creation of intelligent schools in Indonesia, the existence of this model can solve many of the weaknesses in this system. The models introduced in recent years have considered only some of the important features of infrastructure and have not identified the exact road map for the development of intelligent schools. The proposed model will be more applicable by providing a roadmap for solving the infrastructure problem in the development of intelligent schools compared to the models presented in the past, so that by recognizing the dimensions and indicators considered for each dimension, intelligent schools can be improved.

\subsection{Research Limitation}

The reluctance of directors and teachers to change traditional structures and move towards intelligent schools and the lack of cooperation in answering the research questions are due to factors such as teachers' resistance to change, lack of appropriate culture and training in the use of electronic equipment, lack of adequate infrastructure, lack of adequate funding for the implementation of appropriate infrastructure, and poor school management.

\section{Declarations}

\subsection{Data Availability Statement}

The data presented in this study are available in article.

\subsection{Funding}

The author received no financial support for the research, authorship, and/or publication of this article.

\subsection{Institutional Review Board Statement}

Not applicable.

\subsection{Informed Consent Statement}

Not applicable.

\subsection{Declaration of Competing Interest}

The author declares that there is no conflict of interests regarding the publication of this manuscript. In addition, the ethical issues, including plagiarism, informed consent, misconduct, data fabrication and/or falsification, double publication and/or submission, and redundancies have been completely observed by the author.

\section{References}

[1] Alavi, S., Nematbakhsh, N., \& Zeraati, V. (2018). A sustainable model for deployment of mobile learning in schools. International Journal of Mobile Learning and Organisation, 12(2), 113-142. doi:10.1504/IJMLO.2018.090843.

[2] Karakostantaki, E., \& Stavrianos, K. (2021). The use of ICT in teaching religious education in primary school. Education and Information Technologies, 26(3), 3231-3250. doi:10.1007/s10639-020-10417-8.

[3] Abraimova, N. U. (2021). The usage of ict in the classrooms of primary school. Academicia: An International Multidisciplinary Research Journal, 11(4), 1489-1492. doi:10.5958/2249-7137.2021.01253.2.

[4] Alavi, S., \& Aghakhani, H. (2021). Identifying the effect of green human resource management practices on lean-agile (LEAGILE) and prioritizing its practices. International Journal of Productivity and Performance Management, 1-27. doi:10.1108/IJPPM-05-2020-0232. 
[5] Kikis, K., Scheuermann, F., \& Villalba, E. (2010). A framework for understanding and evaluating the impact of information and communication technologies in education. Assessing the Effects of ICT in Education: Indicators, Criteria and Benchmarks for International Comparisons, 69-82. doi:10.1787/9789264079786-en.

[6] Mensah, F. S., \& Agyei, D. D. (2019). Philosophy of teaching, teaching style and ICT use: a qualitative study of the perspectives of high school mathematics teachers. African Journal of Educational Studies in Mathematics and Sciences, 15(1), 1-13. doi:10.4314/ajesms.v15i1.1.

[7] Fu, J. (2013). Complexity of ICT in education: A critical literature review and its implications. International Journal of Education and Development using ICT. Open Campus, The University of the West Indies, West Indies, 9(1), 112-125.

[8] Konasheva, R. A., Kozybaev, E. S., Arzymbetova, S. Z., Berkimbayev, K. M., Kastaev, S. K., Oralbekova, A. K., \& Orazbekuly, K. (2021). Potential of using ICT tools in primary school in the context of inclusive education. Review of International Geographical Education Online, 11(4), 615-626. doi:10.33403/rigeo.800676.

[9] Chan, F. M. (2021). Developing Information Literacy in the Malaysian Smart Schools: Resource-Based Learning as a Tool to Prepare Today's Students for Tomorrow's Society. IASL Annual Conference Proceedings, 203-216. doi:10.29173/iasl8079.

[10] Sundqvist, K., Korhonen, J., \& Eklund, G. (2021). Predicting Finnish subject-teachers' ICT use in Home Economics based on teacher- and school-level factors. Education Inquiry, 12(1), 73-93. doi:10.1080/20004508.2020.1778609.

[11] Tolo, A., Lillejord, S., Flórez Petour, M. T., \& Hopfenbeck, T. N. (2020). Intelligent accountability in schools: A study of how school leaders work with the implementation of assessment for learning. Journal of Educational Change, 21(1), 59-82. doi:10.1007/s10833-019-09359-x.

[12] Alavi, S., \& Mirmohammadsadeghi, S. Introducing a Green Agile Workforce. Journal of Soft Computing and Decision Support Systems, 8(1), 18-24.

[13] Mbuk, R. O. Chemistry Education Infrastructure: A Veritable. In Tool for Achieving National Development Beyond 2020 In Nigeria. Knowledge Review, 33(1),1-5.

[14] Rocha Fernandes, G. W., Rodrigues, A. M., \& Rosa Ferreira, C. A. (2019). Different Theoretical Approaches to the Use of ICT in Science Education. In Using ICT in Inquiry-Based Science Education (pp. 39-58). Springer. doi:10.1007/978-3-030-17895$6 \_2$.

[15] Hubalovsky, S., Hubalovska, M., \& Musilek, M. (2019). Assessment of the influence of adaptive E-learning on learning effectiveness of primary school pupils. Computers in Human Behavior, 92, 691-705. doi:10.1016/j.chb.2018.05.033.

[16] Shanmugam, K., \& Balakrishnan, B. (2019). Motivation in information communication and technology-based science learning in tamil schools. Jurnal Pendidikan IPA Indonesia, 8(1), 141-152. doi:10.15294/jpii.v8i1.16564.

[17] Soegoto, E. S., Yunus, I. P., \& Valentina, T. (2018). Smart School for Senior High School. IOP Conference Series: Materials Science and Engineering, 407(1). doi:10.1088/1757-899X/407/1/012003.

[18] Shoikova, E., Nikolov, R., \& Kovatcheva, E. (2017). Conceptualising of Smart Education. Journal - Electrotechnica \& Electronica (E+E), 52 (3-4), 29-37.

[19] Jalali, Mohmmad Mojtaba., Masoumi, Ali. Farahani, Nodeh Milad., Hezaveh, B. V. (2015). Evaluating the Role of Digitl Media in the Quality of Training Learning Process of Students. In Bachelor of Education Sciences. Bachelor of Education Sciences, Farhangian University, Shahid Bahonar Campus of Arak, Arak, Iran.

[20] Taleb, Z., \& Hassanzadeh, F. (2015). Toward Smart School: A Comparison between Smart School and Traditional School for Mathematics Learning. Procedia - Social and Behavioral Sciences, 171, 90-95. doi:10.1016/j.sbspro.2015.01.093.

[21] Niemi, H. (2014). The Finnish Educational Ecosystem: Working for Equity and High Learning Outcomes. In Finnish Innovations and Technologies in Schools: A guide towards New Ecosystems of Learning. Brill Sense, Paderborn, Germany.

[22] Omidinia, S., Masrom, M., \& Selamat, H. (2013). An Examination of the Concept of Smart School: An Innovation to Address Sustainability. 2nd International Conference on Advances in Computer Science and Engineering (CSE 2013). 2013. doi:10.2991/cse.2013.73.

[23] Soltani, M. (2012). The structure of smart schools in the educational system. Journal of Basic and Applied Scientific Research, 2(6), 6250-6254.

[24] Ilomäki, L. (2008). The effects of ICT on school: teachers' and students' perspectives. Annales Universitatis Turkuensis B 314 , University in Turku, Finland

[25] Rana, M. S., Bhuiyan, T., \& Satter, A. K. M. Z. (2018). E-School: Design and implementation of web based teaching institution for enhancing E-learning experiences. Lecture Notes in Computer Science (Including Subseries Lecture Notes in Artificial Intelligence and Lecture Notes in Bioinformatics), 11055 LNAI, 99-108. doi:10.1007/978-3-319-98443-8_10. 
[26] Ong, E. T., \& Ruthven, K. (2010). The distinctiveness and effectiveness of science teaching in the malaysian "smart school." Research in Science and Technological Education, 28(1), 25-41. doi:10.1080/02635140903513557.

[27] McCahey, A., Allen, K. A., \& Arslan, G. (2021). Information communication technology use and school belonging in Australian high school students. Psychology in the Schools, 58(12), 2392-2403. doi:10.1002/pits.22600.

[28] Ming, T. S., Hall, C., Azman, H., \& Joyes, G. (2010). Supporting Smart School Teachers' Continuing Professional Development in and through ICT: A Model for Change. International Journal of Education and Development Using Information and Communication Technology, 6(2), 5-20.

[29] Bass, B. (2021). The effect of technology funding on school-Level student proficiency. Economics of Education Review, 84, 102151. doi:10.1016/j.econedurev.2021.102151.

[30] Branham, D. (2004). The wise man builds his house upon the rock: The effects of inadequate school building infrastructure on student attendance. Social Science Quarterly, 85(5 SPEC. ISS.), 1112-1128. doi:10.1111/j.0038-4941.2004.00266.x.

[31] Arkorful, V., Barfi, K. A., \& Aboagye, I. K. (2021). Integration of information and communication technology in teaching: Initial perspectives of senior high school teachers in Ghana. Education and Information Technologies, 26(4), 3771-3787. doi:10.1007/s10639-020-10426-7.

[32] Nascimento, M. C., \& Gomes, G. R. R. Teaching continuing training for the use of ICT in the teaching and learning process. Research, Society and Development, 9(2), 33921998.

[33] Katrien, G., (2011). Well-Being at School: Does Infrastructure Matter?. In CELE Exchange. University of Antwwerp, Antwerp, Belgium.

[34] Collins, C., Ruppanner, L., Christin Landivar, L., \& Scarborough, W. J. (2021). The Gendered Consequences of a Weak Infrastructure of Care: School Reopening Plans and Parents' Employment during the COVID-19 Pandemic. Gender and Society, 35(2), 180-193. doi:10.1177/08912432211001300.

[35] Bakar, R. (2018). The influence of professional teachers on Padang vocational school students' achievement. Kasetsart Journal of Social Sciences, 39(1), 67-72. doi:10.1016/j.kjss.2017.12.017.

[36] Wan Zah, W. A., Hajar, M. N., Azimi, H., \& Hayati, A. (2009). The conditions and level of ICT integration in Malaysian Smart Schools. International Journal of Education and Development Using ICT, 5(2), 21-31.

[37] Alavi, S., Peivandzani, S., \& Mirmohammadsadeghi, S. (2021). Risk Assessment and Prioritization of ERP Implementation Based on BSC. Journal of Human, Earth, and Future, 2(1), 16-23. doi:10.28991/hef-2021-02-01-02.

[38] Bakx, A., Samsen-Bronsveld, E., van Elderen, L., \& van Horssen-Sollie, J. (2021). Self-Descriptions of High-Performing and Regular-Performing Primary School Students: An Open, Exploratory Study. Roeper Review, 43(4), $256-271$. doi:10.1080/02783193.2021.1967543.

[39] Ministry of Science, Research and Technology (2021). Draft statement of development strategy of smart schools. Available online: https://www.msrt.ir/fa (accessed on March 2021).

[40] ICT in Schools Advisory Group. (2008). Smart Schools = Smart Economy: Report of the ICT in Schools Joint Advisory Group to the Minister for Education and Science. Dublin: Department of Education and Science.

[41] Hendriks, L., \& Haakma, I. (2019). In which way can teachers contribute to the creative talent development of primary school students?. In Hanze Research Day 2019.

[42] Moxham, B. J., \& Moxham, S. A. (2007). The relationships between attitudes, course aims and teaching methods for the teaching of Gross Anatomy in the Medical Curriculum. European Journal of Anatomy, 11(SUPPL. 1), 19-30.

[43] Kilınç, M. (2019). The Usage Level of Time-Saving Measurement and Evaluation Techniques in Teacher Training Programs. International Education Studies, 12(10), 123. doi:10.5539/ies.v12n10p123.

[44] Du Toit, J. (2016). Teacher training and usage of ICT in education. New directions for the UIS global data collection in the post2015 context (Vol. 16). UNESCO Institute for Statistics.

[45] Jagustović, R., Zougmoré, R. B., Kessler, A., Ritsema, C. J., Keesstra, S., \& Reynolds, M. (2019). Contribution of systems thinking and complex adaptive system attributes to sustainable food production: Example from a climate-smart village. Agricultural Systems, 171, 65-75. doi:10.1016/j.agsy.2018.12.008.

[46] Mangione, G. R. J., \& Cannella, G. (2020). Small School, Smart Schools: Distance Education in Remoteness Conditions. Technology, Knowledge and Learning, 26(4), 845-865. doi:10.1007/s10758-020-09480-4.

[47] Zain, M. Z. M., Murugaiah, P., Atan, H., \& Idrus, R. M. (2004). Management practice in Malaysian Smart School: Tasks and support analysis of the ICT implementation. Proceedings - IEEE International Conference on Advanced Learning Technologies, ICALT 2004, 1008-1012. doi:10.1109/ICALT.2004.1357739. 
[48] Hassan, W. Z. W., Muslim, N., Latiff, R. A., Sallihudin, N. R., \& Citra, P. (2020). Practice in Certain School and Fanatic Inclination to One School: A Study among Malaysian Shafi'i Mazhab Within Islamic Civilization Context. ARPN Journal of Engineering and Applied Sciences, 15(2), 586-595. doi:10.36478/JEASCI.2020.586.595.

[49] Md Zain, A. N., Samsudin, M. A., Rohandi, R., \& Jusoh, A. (2010). Using the Rasch Model to Measure Students’ Attitudes toward Science in "Low Performing" Secondary Schools in Malaysia. International Education Studies, 3(2), 56-63. doi:10.5539/ies.v3n2p56.

[50] Ibrahim, M. S., \& Wekke, I. S. (2009). The Integration of ICT in the Teaching and Learning Processes: A Study on Smart School of Malaysia. 5th WSEAS/IASME International Conference on Educational Technologies (EDUTE’ 09), 189-197.

[51] Kong, S. C., Chan, T. W., Griffin, P., Hoppe, U., Huang, R., Kinshuk, Looi, C. K., Milrad, M., Norris, C., Nussbaum, M., Sharples, M., So, W. M. W., Soloway, E., \& Yu, S. (2013). E-learning in school education in the coming 10 years for developing 21st century skills: Critical research issues and policy implications. Educational Technology and Society, 17(1), 70-78.

[52] Alavi, S., Peivandzani, S., \& Mirmohammadsadeghi, S. (2021). Risk Assessment and Prioritization of ERP Implementation Based on BSC. Journal of Human, Earth, and Future, 2(1), 16-23. doi:10.28991/hef-2021-02-01-02.

[53] Alavi, S., \& Janatyan, N. (2021). Identifying and Prioritizing Activities for Achieving Green Project Management (GPM) in Terms of Lean and Sustainability in the Isfahan Parks and Green Space Organization. Production and Operation Management, Journal of production and operations management, 11(4), 1-24, Isfahan, Iran. doi:10.22108/jpom.2021.126382.1316. 